Prepared in cooperation with the International Joint Commission and the Minnesota Department of Transportation

\title{
Techniques for Estimating the Magnitude and Frequency of Peak Flows on Small Streams in the Binational U.S. and Canadian Lake of the Woods-Rainy River Basin Upstream from Kenora, Ontario, Canada, Based on Data through Water Year 2013
}

Scientific Investigations Report 2019-5012 
Cover. The map, Watershed of the Lake of the Woods, was created by the International Joint Commission between Canada and the United States for an engineering report on water levels of Rainy Lake and other binational border waters, 1928. 


\section{Techniques for Estimating the Magnitude and Frequency of Peak Flows on Small Streams in the Binational U.S. and Canadian Lake of the Woods-Rainy River Basin Upstream from Kenora, Ontario, Canada, Based on Data through Water Year 2013}

By Christopher A. Sanocki, Tara Williams-Sether, Peter A. Steeves, and Victoria G. Christensen

Prepared in cooperation with the International Joint Commission and the Minnesota Department of Transportation

Scientific Investigtions Report 2019-5012 


\title{
U.S. Department of the Interior \\ DAVID BERNHARDT, Secretary
}

\author{
U.S. Geological Survey \\ James F. Reilly II, Director
}

U.S. Geological Survey, Reston, Virginia: 2019

For more information on the USGS - the Federal source for science about the Earth, its natural and living resources, natural hazards, and the environment-visit https://www.usgs.gov or call 1-888-ASK-USGS.

For an overview of USGS information products, including maps, imagery, and publications,

visit https://store.usgs.gov.

Any use of trade, firm, or product names is for descriptive purposes only and does not imply endorsement by the U.S. Government.

Although this information product, for the most part, is in the public domain, it also may contain copyrighted materials as noted in the text. Permission to reproduce copyrighted items must be secured from the copyright owner.

Suggested citation:

Sanocki, C.A., Williams-Sether, T., Steeves, P.A., and Christensen, V.G., 2019, Techniques for estimating the magnitude and frequency of peak flows on small streams in the binational U.S. and Canadian Lake of the Woods-Rainy River Basin upstream from Kenora, Ontario, Canada, based on data through water year 2013: U.S. Geological Survey Scientific Investigations Report 2019-5012, 17 p., https://doi.org/10.3133/sir20195012.

ISSN 2328-0328 (online) 


\section{Contents}

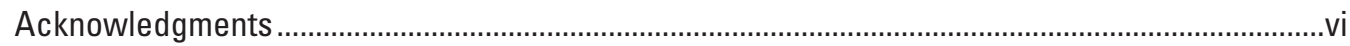

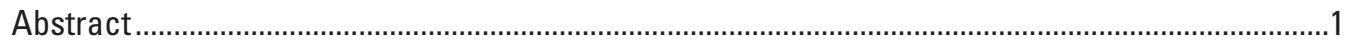

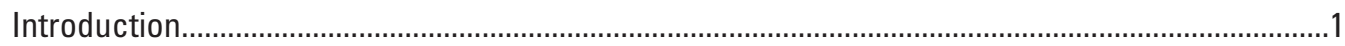

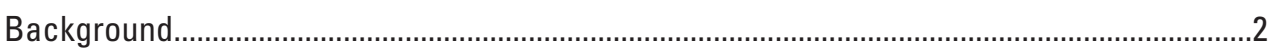

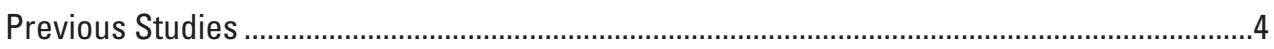

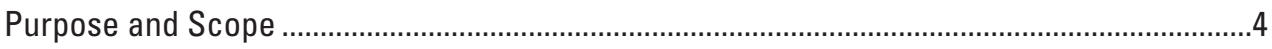

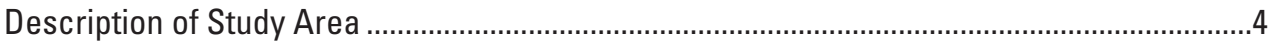

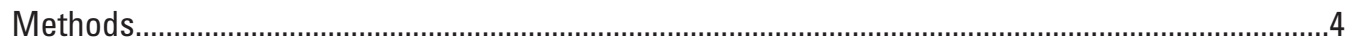

Definition of Peak-Flow Hydrologic Regions.............................................................................6

Techniques for Estimating Peak-Flow Frequency ..............................................................6

Peak-Flow Data ...............................................................................................................

Frequency Analysis of Annual Peak-Flow Data at Selected Streamgages .......................7

Estimating Basin Characteristics ...........................................................................................8

Methods Used to Define Peak-Flow Hydrologic Regions ......................................................

Development of Regional Regression Equations ...............................................................................

Accuracy and Limitations of the Regional Regression Equations............................................11

Web Application for Solving Regional Regression Equations..................................................11

Application of Regional Regression Equations..................................................................................11

Estimating the Weighted Peak-Flow Frequency for a Streamgage .........................................11

Estimating the Peak-Flow Frequency for an Ungaged Site .......................................................12

Regression-Weighted and Area-Weighted Estimates for an Ungaged Site on a

Gaged Stream .......................................................................................................... 12

Additional Considerations for Applying Peak-Flow Estimation Techniques ...........................13

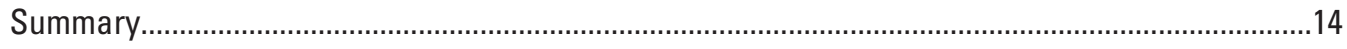

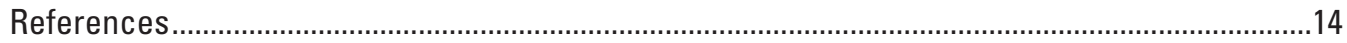




\section{Figures}

1. Map showing streamgages used to estimate peak-flow frequencies and magnitudes for new hydrologic region B1, which represents the Lake of the Woods-Rainy River Basin upstream from Kenora, Ontario, Canada...

2. Map showing hydrologic peak-flow regions for Ontario, Canada, and the U.S. States of lowa, Minnesota, North Dakota, South Dakota, and Wisconsin designated by numbers and letters in the United States and by letter A in Canada

\section{Tables}

1. Hydrologic, basin, and climatic characteristics and peak-flow frequency discharges for streamgages used in the regional regression analysis for the Lake of the Woods-Rainy River Basin available for download at https://doi.org/10.3133/sir20195012

2. Example application of the Sangal (1983) method equations 1 and 2 to estimate station averaged base factor $\mathrm{K}$ value and estimate of unknown instantaneous peak for 1993.

3. Regional regression equations for peak-flow frequency estimates in the Lake of the Woods-Rainy River Basin

4. Regional exponent determined from regional regression of log-transformed (base-10) drainage area for an area-weighted ratio method to estimate peak-flow frequency for an ungaged site on a gaged stream in Lake of the Woods-Rainy River Basin

\section{Conversion Factors}

U.S. customary units to International System of Units

\begin{tabular}{lcl}
\hline & Multiply & \multicolumn{1}{c}{ By obtain } \\
\hline & Length & \\
\hline foot $(\mathrm{ft})$ & 0.3048 & meter $(\mathrm{m})$ \\
mile $(\mathrm{mi})$ & 1.609 & kilometer $(\mathrm{km})$ \\
\hline & Area & \\
\hline square mile $\left(\mathrm{mi}^{2}\right)$ & 259.0 & hectare $(\mathrm{ha})$ \\
square mile $\left(\mathrm{mi}^{2}\right)$ & 2.590 & square kilometer $\left(\mathrm{km}^{2}\right)$ \\
\hline & Flow rate & \\
\hline cubic foot per second $\left(\mathrm{ft}^{3} / \mathrm{s}\right)$ & 0.02832 & cubic meter per second $\left(\mathrm{m}^{3} / \mathrm{s}\right)$ \\
\hline
\end{tabular}

Temperature in degrees Celsius $\left({ }^{\circ} \mathrm{C}\right)$ may be converted to degrees Fahrenheit ( $\left.{ }^{\circ} \mathrm{F}\right)$ as follows ${ }^{\circ} \mathrm{F}=\left(1.8 \times{ }^{\circ} \mathrm{C}\right)+32$.

Temperature in degrees Fahrenheit $\left({ }^{\circ} \mathrm{F}\right)$ may be converted to degrees Celsius $\left({ }^{\circ} \mathrm{C}\right)$ as follows ${ }^{\circ} \mathrm{C}=\left({ }^{\circ} \mathrm{F}-32\right) / 1.8$. 


\section{Supplemental Information}

A water year is the 12-month period from 0ctober 1 through September 30 and is designated by the year in which it ends.

\section{Abbreviations}

$\begin{array}{ll}\text { AEPD } & \text { annual exceedance-probability discharge } \\ \text { AVP } & \text { average variance of prediction } \\ \text { B17B } & \text { Bulletin 17B } \\ \text { DEM } & \text { digital elevation model } \\ \text { EMA } & \text { expected moments algorithm } \\ \text { EPA } & \text { U.S. Environmental Protection Agency } \\ \text { FEMA } & \text { Federal Emergency Management Agency } \\ \text { GIS } & \text { geographic information system } \\ \text { GLS } & \text { generalized least squares } \\ \text { IJC } & \text { International Joint Commission } \\ \text { LOW-RRB } & \text { Lake of the Woods-Rainy River Basin } \\ \text { MGB } & \text { Multiple Grubbs Beck } \\ \text { MNDNR } & \text { Minnesota Department of Natural Resources } \\ \text { NWIS } & \text { National Water Information System } \\ \text { OLS } & \text { ordinary least squares } \\ \text { OMNRF } & \text { Ontario Ministry of Natural Resources and Forestry } \\ \text { PILF } & \text { potentially influential low flow } \\ R^{2} & \text { coefficient of determination } \\ \text { SME } & \text { standard model error } \\ S_{\mathrm{p}} & \text { standard error of prediction } \\ \text { USGS } & \text { U.S. Geological Survey }\end{array}$




\section{Acknowledgments}

The authors thank Nolan Baratono, International Rainy-Lake of the Woods Watershed Board, and Mike Laitta, International Joint Commission, for their time, energy, and coordination of meetings; and Judy Kwan and Gail Faveri of Environment and Climate Change Canada for their support of the project and assistance with the collection of streamflow data in Canada.

The authors also want to thank Daniel Morel, Catherine Christenson, and Jeff Ziegeweid, U.S. Geological Survey, for assisting with analyses and review. 


\title{
Techniques for Estimating the Magnitude and Frequency of Peak Flows on Small Streams in the Binational U.S. and Canadian Lake of the Woods-Rainy River Basin Upstream from Kenora, Ontario, Canada, Based on Data through Water Year 2013
}

\author{
By Christopher A. Sanocki, Tara Williams-Sether, Peter A. Steeves, and Victoria G. Christensen
}

\section{Abstract}

A binational study was initiated to update statistical equations that are used to estimate the magnitude and frequency of peak flows on streams in Manitoba and Ontario, Canada, and Minnesota that are contained within the binational Lake of the Woods-Rainy River Basin upstream from Kenora, Ontario, Canada. Hydraulic engineers use peak streamflow data to inform designs of bridges, culverts, and dams, and water managers use peak streamflow data to inform regulation and planning activities. However, long-term streamflow measurements are available at few locations along the more than 20,000 miles of stream/ditch networks within the binational Lake of the Woods-Rainy River Basin upstream from Kenora, Ontario, Canada.

Estimates of peak-flow magnitudes for 66.7-, 50-, 20-, 10-, 4-, 2-, 1-, and 0.2-percent annual exceedance probabilities equivalent to annual flood-frequency recurrence intervals of 1.5-, 2-, 5-, 10-, 25-, 50-, 100-, and 500-year recurrence intervals, respectively, are presented for 49 streamgages in Minnesota and adjacent areas in the Province of Ontario, Canada, based on data collected through water year 2013. Peak-flow frequency information was subsequently used in regression analyses to develop equations relating peak flows for selected recurrence intervals to various basin and climatic characteristics.

The study area includes 49 streamgages located in the binational Lake of the Woods-Rainy River Basin upstream from Kenora, Ontario, Canada, and is represented by southern portions of the Canadian Provinces of Manitoba (2 percent) and Ontario (56 percent) and the northern portion of the U.S. State of Minnesota (42 percent). The study area was represented by three regions that were defined in previous studies in the U.S. State of Minnesota and another in the Canadian Province of Ontario. The two Minnesota regions A and B were developed using a multiple regression method and hydrologic landscape units were used to validate regions in Minnesota. The Ontario region A was developed using a multiple regression method and standardized residuals from the 100-year recurrence intervals.

Canadian maximum instantaneous peak-flow data were converted from a calendar year to a water year (October 1 to September 30) and where the annual maximum instantaneous peak-flow value was not available in HYDAT, the Sangal method was applied to known average daily flow values to estimate an annual maximum instantaneous peak-flow value. Geographic information system software was used to calculate eight characteristics investigated as potential explanatory variables in the regression analyses.

The procedure for estimating peak-flow frequency for selected exceedance probabilities for a specific ungaged site depends on whether the site is near a streamgage on the same stream or is on an ungaged stream. For an ungaged site near a streamgage on the same stream, the drainage-area ratio method can be used. For an ungaged site on an ungaged stream, the regional regression equations developed for this study should be used.

All equations presented in this study will be incorporated into StreamStats, a web-based geographic information system tool developed by the U.S. Geological Survey. StreamStats allows users to obtain streamflow statistics, basin characteristics, and other information for user-selected locations on streams through an interactive map.

\section{Introduction}

Tools to estimate peak streamflow at user-selected locations along streams are needed for the management of water within the binational Lake of the Woods-Rainy River Basin (LOW-RRB). Estimates of annual exceedance-probability discharges (AEPDs) are essential for the engineering of 
bridges, dams, and levees; flood-plain mapping; and evaluating the influence of streamflow on high priority binational environmental and water-management challenges. For example, 1- and 0.2-percent AEPDs are used in the design for, and estimate of, scour at bridges (Arneson and others, 2012; Fischer, 1995). In addition, 1- and 0.2-percent AEPDs are used on the United States side of the LOW-RRB to inform management of flood-plain development through the National Flood Insurance Program, administered by the Federal Emergency Management Agency (FEMA; Federal Emergency Management Agency, 2002). However, long-term streamflow data are available from few streamgages in the LOW-RRB. Therefore, statistical techniques are needed to estimate peak flow associated with specified AEPDs at ungaged sites.

Daily mean and annual peak-discharge data from streamgages operated by Environment and Climate Change Canada, along with continuous and annual peak-flow streamgages operated by the U.S. Geological Survey (USGS), were used for this analysis. Regression analyses were used to develop statistical equations to estimate AEPDs for ungaged locations. The equations were developed by statistically relating AEPDs to significant basin characteristics for selected streamgages located within the LOW-RRB. The AEPDs computed for streamgages can change as additional annual peak-discharge data become available. Furthermore, the statistics become more reliable as longer-term data are collected and used in the development of the computations. Hydrologic engineers continually evaluate the effectiveness of the streamgage network - streamgages are added where flow data are needed and discontinued where additional data are less critical.

\section{Background}

Canadian and U.S. environmental agencies have been cooperating in an effort to harmonize digital lake, stream, and watershed data along the 8,000-kilometer (5,500 mile) border following the approach of the International Watersheds Initiative (2013). This effort completed the harmonization of Canadian hydrography data (digital rivers, lakes, and watersheds) with U.S. hydrography data for the LOW-RRB, a watershed straddling the Canadian Provinces of Manitoba and Ontario and the U.S. State of Minnesota (fig. 1). The harmonized hydrography has generated interest in sharing applications that are used to help water managers estimate peak flows on streams.

The International Joint Commission (IJC) funded an effort to process a portion of the binational harmonized hydrography data for the implementation of USGS StreamStats (https://streamstats.usgs.gov/ss/) for the LOW-RRB as described in Project 30 of International Lake of the Woods Basin Water Quality Plan of Study (Agreement 1042-000743, Amendment 2 1042-200756; International Lake of the Woods Basin Water Quality Plan of Study Team, 2014). The work included (1) developing regional regression equations for estimating peak-flow frequencies, (2) processing the binational harmonized hydrography data and other geospatial datasets needed for StreamStats, (3) adding streamgage information into a database to facilitate serving the information by way of the web, and (4) developing a framework for publishing the regression equations.

This effort, in collaboration with the IJC, is important to several related issues in the basin. The International RainyLake of the Woods Watershed board and the Minnesota Pollution Control Agency is currently working on nutrient loading for Lake of the Woods (Lake of the Woods Soil and Water Conservation District, 2016). In addition, new mining activities have started in watersheds of Canadian tributaries to Rainy River, and there are proposed mining activities in the upper portion of the U.S. side of the LOW-RRB. Finally, this effort provides information that helps the IJC manage water levels in international border waters. Regularly updated rule curves are used to regulate water levels in Namakan and Rainy Lakes (Ziegeweid and others, 2016).

Completion of this study improved communication and cooperation among environmental agencies represented in the LOW-RRB. On the Canadian side of the LOW-RRB, Environment and Climate Change Canada provided links to Canadian streamflow data and leadership and participation on the binational watershed harmonization project. In addition, Ontario Ministry of Natural Resources and Forestry agreed to assist with the selection of streamgages and expressed interest in reviewing and sharing methods used to produce streamflow statistical equations. Finally, Agriculture and Agri-Food Canada was a lead agency in the binational watershed and hydrography harmonization initiatives. On the U.S. side of the LOW-RRB, the USGS, Minnesota Department of Transportation, Minnesota Department of Natural Resources (MNDNR), Minnesota Pollution Control Agency, and Minnesota Geospatial Information Office have cooperated with Canadian environmental agencies on hydrological harmonization and efforts to share data, methods, and tools used for streamflow estimation.

Streamflow records in Canada's national water data archive HYDAT (Water Survey of Canada, 2016) show that streamflow measurements started in about 1860, and a gaging effort to obtain daily flow data was initiated in Minnesota around 1909 (U.S. Geological Survey, 2018). The longest streamflow record on the Canadian side of the LOW-RRB is the Turtle River near Mine Centre (fig. 1, map number C1), which has operated continuously since 1914 . The oldest sites on the U.S. side of the LOW-RRB are represented by the Little Fork River at Littlefork, Minnesota (1910-17 and 1929-present), and the Big Fork River at Big Falls, Minnesota (1910-12, 1929-94, and 1998-present; fig. 1, map numbers 24 and 27). A USGS water year was used for the U.S. and Canadian data. A USGS water year is the 12-month period from October 1 through September 30 and is designated by the year in which it ends. 

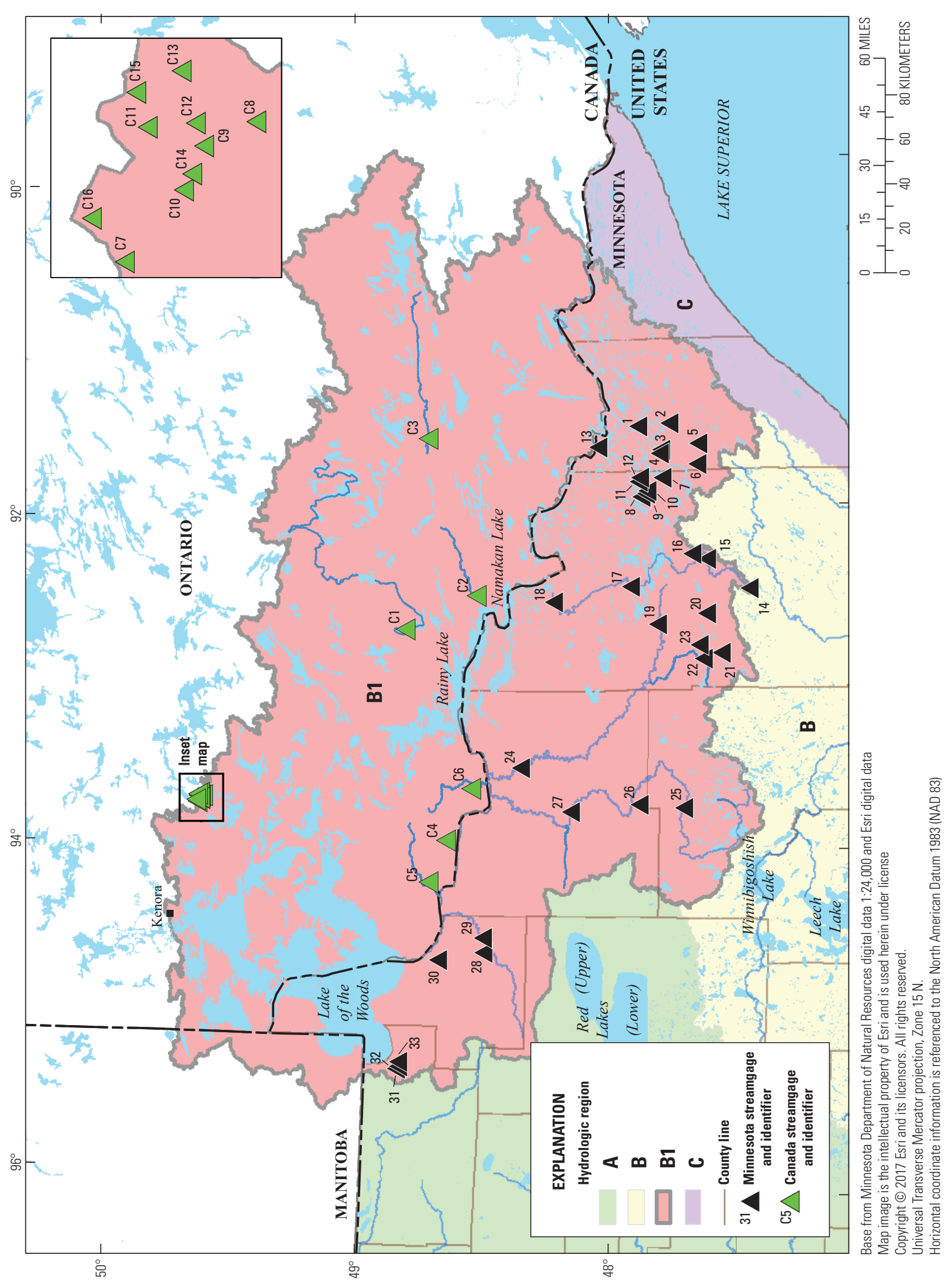

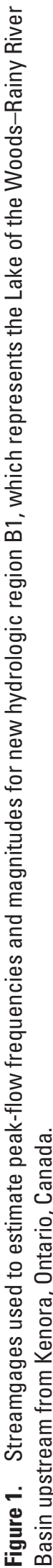




\section{Previous Studies}

Previous studies in the LOW-RRB (Prior, 1949; Prior and Hess, 1961; Wiitala, 1965; Patterson and Gamble, 1968; Guetzkow, 1977; Sangal, 1983; Moin and Shaw, 1985;

Jacques and Lorenz, 1987; Lorenz and others, 1997, 2010; Kessler and others, 2013; Lorenz and Ziegeweid, 2016; Ziegeweid and others, 2015) have provided flow frequency information at selected streamgages and methods for calculating flow frequency data at ungaged sites in Minnesota. Regulated streamgages were not used in the analysis of smaller events such as the 2-, 5-, 10-, and 25-year peak flows but were included in the analysis of 50- and 100-year return period peak flows with the premise that regulation has less effect on larger events (Moin and Shaw, 1985; Ontario Ministry of Natural Resources and Forestry, 2013). Analysis of annual peak-flow records for the first of these reports that used the Log Pearson Type III method of analysis (Guetzkow, 1977) may not have included information about historical floods that occur before the systematic collection of data, and the period of record for many streams was very short from the standpoint of flood history. Guetzkow (1977) included most of the long-term record stations with low annual peaks from the 1930s drought and high annual peaks from the 1950s and 1960s. Historical flood information was incorporated in the analysis done in subsequent reports. Jacques and Lorenz (1987) also used fewer regions than Guetzkow (1977), which resulted in larger standard errors of estimate for the regional equations. Lorenz (1997) produced station skews for 267 long-term streamgages in Minnesota and surrounding States and Provinces to produce a generalized skew coefficient map. Lorenz and others (2010) used two statistical techniques - regional regression equation and region of influence - to estimate peak flows. Lorenz and others (2010) also used hydrologic landscape units (Winter, 2001; Wolock and others, 2004) to validate and update hydrologic regions for Minnesota. Because of the need for up-to-date peak-flow frequency information and to estimate peak flows at ungaged sites for the binational LOW-RRB, the USGS initiated a peak-flow frequency study in cooperation with the IJC and the Minnesota Department of Transportation.

\section{Purpose and Scope}

The purposes of this report are to (1) describe the methods and results of the analysis of peak-flow frequency at selected streamgages for the combined U.S. and Canadian area of the LOW-RRB, and (2) document a statistically derived technique for estimating peak-flow data at ungaged sites on small unregulated streams. Peak-flow frequency estimates were developed for 49 streamgages using data through USGS water year 2013.

Regional regression equations for estimating peak-flow data at ungaged sites are described in this report. Streams used in this analysis were mostly unaffected by urban development; therefore, use of regression equations for analyses in dense urban settings is not recommended. Streamgages with drainage areas greater than 3,000 square miles were not included in this analysis because of the likelihood of regulation on rivers of that size. Other streamgages that were not included in this analysis had peak flows that were affected by controlled storage or regulated releases.

\section{Description of Study Area}

The study area (fig. 1) includes the entire Lake of the Woods-Rainy River Basin upstream from Kenora in Ontario, Canada. The LOW-RRB is represented in the Canadian Provinces of Manitoba (2 percent) and Ontario (56 percent) and the U.S. State of Minnesota (42 percent).

The study area was previously represented by three hydrologic regions (fig. 2) developed using a combination of statistical analyses from previous studies (Eash and others, 2013; Lorenz and others, 2010; Ontario Ministry of Natural Resources and Forestry, 2013; Sando and others, 2008; Walker and Krug, 2003; Williams-Sether, 2015). Streamgages included in this study were assigned a map number, and information associated with each map number (streamgage) can be found in table 1 (available for download at https://doi. org/10.3133/sir20195012). Descriptions of differences among each hydrologic region represented in the LOW-RRB are described in the next section.

\section{Methods}

Region B1, which represents the LOW-RRB, was developed by referencing previous reports from the Canadian Province of Ontario and the U.S State of Minnesota (Ontario Ministry of Natural Resources and Forestry, 2013 and Lorenz and others, 2010). The final regression equations were chosen based on minimizing values of the standard model error and the standard error of prediction, maximizing values of the pseudo coefficient of determination, and examination of regression residuals. Data for 49 active and inactive streamgages located in the Province of Ontario, Canada, and the U.S. State of Minnesota were used in this report (fig. 1; table 1). Selected streamgages met the following criteria: (1) at least 10 complete water years of reported annual peak flow or a combination of reported annual peak flow and daily mean streamflows; (2) streamflows unaffected by regulation, diversion, or urbanization; and (3) drainage areas less than 3,000 square miles. Geographic information system (GIS) software was used to calculate eight physical characteristics investigated as potential explanatory variables in regression analyses. 


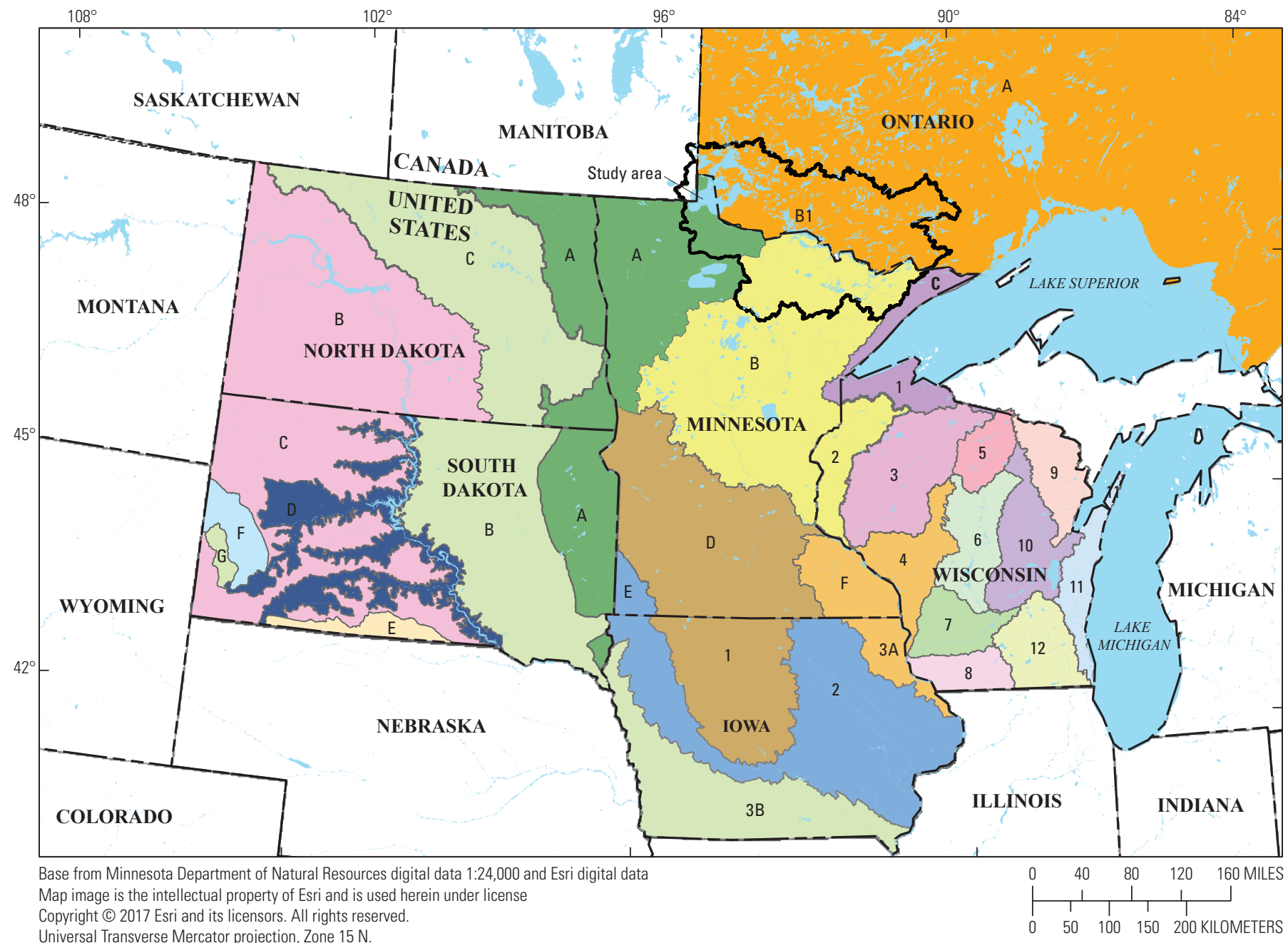

Univist 2017 Esiand its licensors. All rights reserve

Horizontal coordinate information is referenced to the North American Datum 1983 (NAD 83)

\section{EXPLANATION}

\begin{tabular}{|c|c|}
\hline B1 & Lake of the Woods-Rainy River Basin \\
\hline & $\begin{array}{l}\text { North Dakota hydrologic regions } \\
\text { established by previous research }\end{array}$ \\
\hline A & Williams-Sether, 2015 \\
\hline B & Williams-Sether, 2015 \\
\hline C & Williams-Sether, 2015 \\
\hline & $\begin{array}{l}\text { South Dakota hydrologic regions } \\
\text { established by previous research }\end{array}$ \\
\hline A & Sando and others, 2008 \\
\hline B & Sando and others, 2008 \\
\hline C & Sando and others, 2008 \\
\hline D & Sando and others, 2008 \\
\hline$E$ & Sando and others, 2008 \\
\hline $\mathrm{F}$ & Sando and others, 2008 \\
\hline G & Sando and others, 2008 \\
\hline
\end{tabular}

Ontario, Canada, hydrologic regions established by previous research

A Ontario Ministry of Natural Resources and Forestry, 2013

Minnesota hydrologic regions established by previous research

Lorenz and others, 2010

B Lorenz and others, 2010

Lorenz and others, 2010

Lorenz and others, 2010

Lorenz and others, 2010

lowa hydrologic regions established by previous research

Eash and others, 2013

Eash and others, 2013

Eash and others, 2013

Eash and others, 2013
Wisconsin hydrologic regions established by previous research Walker and Krug, 2003

Walker and Krug, 2003

Walker and Krug, 2003

Walker and Krug, 2003

Walker and Krug, 2003

Walker and Krug, 2003

Walker and Krug, 2003

Walker and Krug, 2003

Walker and Krug, 2003

Walker and Krug, 2003

Walker and Krug, 2003

Walker and Krug, 2003

Figure 2. Hydrologic peak-flow regions for Ontario, Canada, and the U.S. States of lowa, Minnesota, North Dakota, South Dakota, and Wisconsin (Eash and others, 2013; Lorenz and others, 2010; Ontario Ministry of Natural Resources and Forestry, 2013; Sando and others, 2008; Walker and Krug, 2003; Williams-Sether, 2015) designated by numbers and letters in the United States and by letter A in Canada. 


\section{Definition of Peak-Flow Hydrologic Regions}

The LOW-RRB includes two of the regions defined by Lorenz and others (2010; fig. 1). Region A represents one of the most heterogeneous regions with low slopes and moderate slopes along drainage boundaries and primarily consists of the Red River Basin, which flows north into Canada. Region $\mathrm{B}$ is dominated by sandy soil groups with varying slopes and includes the upper Mississippi River headwaters and the south-central portion of the LOW-RRB represented with thousands of large and small lakes and wetlands.

Previous State and Province reports developed hydrologic regions using an analysis of the pattern of residuals of state/province-wide regressions to assist in the delineation of peak-flow hydrologic regions. Explanatory variables such as base flow index, drainage area, main-channel slope, lake area, shapefactor (calculated as a ratio of basin length squared divided by drainage area), mean annual precipitation, storage area (area of lakes and wetlands), and mean annual runoff were used for regional regression analysis. The hydrologic region for the Province of Ontario (Ontario Ministry of Natural Resources and Forestry, 2013) and neighboring U.S. States of Iowa (Eash and others, 2013), Minnesota (Lorenz and others, 2010), North Dakota (Williams-Sether, 2015), South Dakota (Sando and others, 2008) and Wisconsin (Walker and Krug, 2003) are shown in figure 2. The six peak-flow region GIS datasets were assembled, one for each of the five States and one Canadian Province, and were harmonized by color along State and Provincial boundaries. It is encouraging to note how closely each State and Province peak-flow region align even though various statistical methods and physical characteristics were used in their development. The hydrologic region for the LOW-RRB (B1) was modified from hydrologic regions A and B for Minnesota (Lorenz and others, 2010) and Ontario region A (figure 11 in Ontario Ministry of Natural Resources and Forestry, 2013). Most of the new region B1 is represented by surficial bedrock overlain with greater than 30,000 large, medium, and small lakes and wetlands. It includes high, moderate, and low slopes in the very southwest portion of the region B1. Region B1 boundaries followed 8-digit hydrologic unit boundaries (U.S. Geological Survey, 2013; Laitta, 2010) so that the drainage area of a small stream will not overlap two regions, making interpretation easier for all streams. The southwestern portion of region B1 is more closely associated with region A in Minnesota (Lorenz and others, 2010) but was lumped into B1 to capture all the LOW-RRB flow.

\section{Techniques for Estimating Peak-Flow Frequency}

This section describes the techniques, methods, and computations of the analysis of peak-flow frequency at selected streamgages in Minnesota and the Provinces of Manitoba and Ontario, Canada. The methods and analyses that were required to develop the techniques for estimating peak-flow data on small ungaged streams are described. This section also presents preliminary computations of basin characteristics required for regression analysis.

\section{Peak-Flow Data}

Streamflow records selected for analysis in this study consisted of unregulated annual peak-flow data of at least 10 years (Interagency Advisory Committee on Water Data, 1982) through water year 2013 from streamgages in Minnesota and the Province of Ontario, Canada, within the LOW-RRB. The streamgages selected included 33 from Minnesota and 16 from Canada. The Minnesota peak-flow data were obtained from the USGS National Water Information System (NWIS) peak-flow file (U.S. Geological Survey, 2018) and the Canadian peakflow data were obtained from the HYDAT database (Water Survey of Canada, 2016). Minnesota streamgages used in this study included those with continuous record that documented daily streamflow and crest-stage partial record streamgages that documented only annual peak flow. These streamgages were verified for completeness of record. Many of the Minnesota and Canadian streamgages were seasonal partial record and only operated for part of the year, mainly March through December. The annual peak flow for Minnesota streamgages consisted of the maximum instantaneous discharge for the water year. The annual peak flow for the Canadian streamgages consisted of maximum instantaneous discharge for a calendar year (the 12-month period of January 1 through December 31 for any given year).

Several data issues for the Canadian peak-flow data needed to be addressed prior to being used in this study. This was done to be consistent with USGS peak-flow data formats. First, all Canadian peak-flow data were converted from cubic meters per second to cubic feet per second. Second, where needed, the Canadian maximum instantaneous peak-flow data were converted from a calendar year to a water year. Third, where the annual maximum instantaneous peak-flow value was not available in HYDAT, the Sangal (1983) method was applied to known average daily flow values to estimate an annual maximum instantaneous peak-flow value.

The method presented by Sangal (1983), herein referred to as the Sangal method, described as follows by Sehgal (2016), uses the average daily flow for 3 consecutive days (Q1, Q2, and Q3). The second position (Q2) is the annual maximum average daily flow value for the water year. A parameter called the base factor K is employed by the Sangal (1983) method, which is the base of an assumed triangular hydrograph. The base factor $\mathrm{K}$ is an important parameter and should be estimated for small basins. The general form of the relation between the instantaneous peak flow and average daily flow for any year is shown in equation 1. For Canadian streamgages with years having annual maximum instantaneous peak flow and annual maximum average daily flow data, equation 1 was used to estimate the base factor $\mathrm{K}$ for each year of known values. Estimated yearly base factor $\mathrm{K}$ values were then averaged to determine an average base factor value, $K(a)$, for each streamgage (table 2). The streamgage averaged base factor value, $\mathrm{K}(\mathrm{a})$, was then 
used in equation 2 to predict the annual maximum instantaneous peak-flow value for the years that needed the annual maximum instantaneous peak flow estimated.

$$
\begin{gathered}
K=(4 Q 2-2 Q 1-2 Q 3) /(2 Q P-Q 1-Q 3) \\
Q P^{\prime}=(Q 1+Q 3) / 2+[2 Q 2-Q 1-Q 3] / K(a)
\end{gathered}
$$

where

$K \quad \begin{gathered}\text { is the estimated base factor } \mathrm{K} \text { for each } \\ \text { year; } \\ \text { represents the average daily flow value 1 day } \\ \text { before the water year maximum daily flow } \\ \text { value (cubic feet per second); } \\ \text { represents the water year maximum average } \\ \text { daily flow value (cubic feet per second); } \\ \text { represents the average daily flow value 1 day } \\ \text { after the water year maximum average } \\ \text { daily flow (cubic feet per second); }\end{gathered}$
$\begin{gathered}\text { is the known annual maximum instantaneous } \\ \text { peak-flow value (cubic feet per second); }\end{gathered}$
$\begin{gathered}\text { is the estimated annual maximum } \\ \text { instantaneous peak-flow value (cubic feet } \\ \text { per second); and }\end{gathered}$
$\begin{gathered}\text { is the averaged base factor K for a } \\ \text { streamgage. }\end{gathered}$

Water years for which the annual maximum instantaneous peak-flow value was estimated using the Sangal method are listed in table 1.

\section{Frequency Analysis of Annual Peak-Flow Data at Selected Streamgages}

As stated in Williams-Sether (2015), peak-flow frequency analysis is a statistical technique used to estimate flood discharges associated with known exceedance probabilities. Exceedance probability is the chance or likelihood that a given flow of specific magnitude will happen in any 1-year period. Exceedance probabilities formerly were reported as flood recurrence intervals expressed in years. For example, a flood magnitude that has a 1-percent chance (exceedance probabil$i t y=0.01$ ) of being exceeded during any year is expected to be exceeded on average once during any 100-year period (recurrence interval). Percent exceedance probability is the inverse of the recurrence interval multiplied by 100 . Although the exceedance probability is an estimate of the likelihood in any 1 -year period, more than one flood discharge with a specific magnitude and exceedance probability could happen in the same 1-year period.

The peak-flow frequency estimates in this report were computed using the USGS program PeakFQ, version 7.2 (Veilleux and others, 2014; Flynn and others, 2006), which performs statistical flood-frequency analyses of annual peak flows following procedures recommended in Bulletin 17B (B17B) of the Interagency Advisory Committee on Water Data (1982) and modified by the Advisory Committee on Water Information, Subcommittee on Hydrology, Hydrologic Frequency Analysis Work Group. The expected moments algorithm (EMA) with the multiple Grubbs-Beck (MGB) test option (England, 2018) in PeakFQ was used for the peak-flow analyses. The EMA addresses several methodological concerns

Table 2. Example application of the Sangal (1983) method equations 1 and 2 to estimate station averaged base factor $\mathrm{K}$ value and estimate of unknown instantaneous peak for 1993.

$\left[\mathrm{m}^{3} / \mathrm{s}\right.$, cubic meter per second; $\mathrm{QP}$, known annual maximum instantaneous peak-flow value; $\mathrm{ft} / \mathrm{s}$; cubic foot per second; Q1, average daily flow value 1 day before water year maximum average daily flow value; Q2, water year maximum average daily flow value; Q3, average daily flow value 1 day after water year maximum average daily flow value; K, estimated base factor K for each year; --, no data; K(a), averaged base factor K; QP', estimated annual maximum instan-

\begin{tabular}{|c|c|c|c|c|c|c|c|c|c|}
\hline $\begin{array}{c}\text { Canadian } \\
\text { station }\end{array}$ & $\begin{array}{c}\text { Calendar } \\
\text { year }\end{array}$ & $\begin{array}{c}\text { Known } \\
\text { annual maxi- } \\
\text { mum instan- } \\
\text { taneous peak } \\
\text { flow } \\
\left(\mathrm{m}^{3} / \mathrm{s}\right)\end{array}$ & $\begin{array}{l}\text { Month and day } \\
\text { of known } \\
\text { annual } \\
\text { maximum } \\
\text { instantaneous } \\
\text { peak flow }\end{array}$ & $\underset{\left(\mathrm{ft}^{3} / \mathrm{s}\right)}{\mathrm{OP}}$ & $\begin{array}{c}01 \\
\left(\mathrm{ft}^{3} / \mathrm{s}\right)\end{array}$ & $\begin{array}{c}02 \\
\left(\mathrm{ft}^{3} / \mathrm{s}\right)\end{array}$ & $\begin{array}{c}03 \\
\left(\mathrm{ft}^{3} / \mathrm{s}\right)\end{array}$ & $\begin{array}{l}\text { Month and } \\
\text { day of } 02\end{array}$ & K \\
\hline 05PD031 & 1988 & 0.027 & $7 / 7$ & 0.953496 & 0.141259 & 0.706293 & 0.388461 & $7 / 7$ & 1.282051 \\
\hline 05PD031 & 1991 & 0.01 & $5 / 23$ & 0.353147 & 0.035315 & 0.317832 & 0.247203 & $5 / 23$ & 1.666667 \\
\hline 05PD031 & 1992 & 0.03 & $6 / 28$ & 1.059440 & 0.211888 & 0.741608 & 0.388461 & $6 / 28$ & 1.162791 \\
\hline 05PD031 & 1993 & -- & -- & -- & -- & -- & -- & -- & -- \\
\hline 05PD031 & 1994 & 0.043 & $9 / 16$ & 1.518531 & 0.141259 & 1.130069 & 0.882867 & $9 / 16$ & 1.228070 \\
\hline
\end{tabular}
taneous peak-flow value] 
identified in $\mathrm{B} 17 \mathrm{~B}$ while retaining the essential structure and moments-based approach of the existing B17B procedures for determining flood frequency. The EMA can accommodate interval data, which simplifies analysis of datasets containing censored observations, historic and (or) paleo data, low outliers, and uncertain data points while also providing enhanced confidence intervals on the estimated discharges.

Unlike B17B, which recognizes two categories of data-systematic peaks (annual peaks observed in the course of systematic streamgaging at the station) and historic peaks (records of floods that occurred outside the period of regular streamgaging) - EMA employs a more general description of flood information from the historical period that includes systematic and historic peaks. For every year $(\mathrm{Y})$ during the historical period, it is assumed that there was a peak discharge (QY), regardless of whether this discharge was recorded. In the framework of EMA, the hydrologist's knowledge of the peak-flow QY is described by the flow interval (QY,lower; QY,upper). The interval is based on a lower (QY,lower) and upper (QY,upper) estimate (in other words, the interval) and is made based on observations, written records, or physical evidence. When running EMA, a flow interval must be specified for each year in the historical record, including any gaps for which no discharge observation is recorded, as well as for censored and interval peaks. EMA distinguishes among sampling properties by employing perception thresholds denoted (TY,lower; TY,upper), which reflect the range of flows that would have been measured/recorded had they occurred. Perception thresholds describe the range of measurable potential discharges and are independent of the actual peak discharges that have occurred. The lower bound (TY,lower) represents the smallest peak flow that would result in a recorded flow, whereas the upper bound (TY,upper) represents the largest peak flow that would result in a measured flow (Veilleux and others, 2014).

The Grubbs-Beck test (Grubbs and Beck, 1972) is recommended by B17B to detect low outliers in flood-frequency analysis. As described by Cohn and others (2013), the MGB test is a generalization of the Grubbs-Beck method that allows for a standard procedure for identifying multiple potentially influential low flows (PILFs). In flood-frequency analysis, PILFs are annual peaks that meet three criteria: (1) their magnitude is much smaller than the flood quantile of interest; (2) they occur below a statistically significant break in the floodfrequency data plot; and (3) they have excessive influence on the estimated frequency of large floods. When an observation is identified as a PILF, all values smaller than that flood are also categorized as PILFs. Identifying PILFs and recording them as censored peaks can greatly improve estimator robustness with little or no loss of efficiency. Thus, the use of the MBG test can improve the fit of the small annual exceedance probabilities while minimizing lack of fit caused by unimportant PILFs in an annual peak series (Cohn and others, 2013; Veilleux and others, 2014).

Procedures in B17B recommend the use of a skew coefficient that is based on the skew of the log series of the period of record (commonly termed the "station skew") weighted with a generalized, or regional, skew coefficient. The weighting is based on the length of the period of record and the estimated standard error for the method used to determine the generalized skew coefficient. The generalized skew coefficients for the Minnesota streamgages used in the peak-flow frequency analysis for this report were based on a generalized skew grid developed by Lorenz (1997); however, the generalized skew grid did not extend far enough north into the LOWRRB to include all the Canadian streamgages. A computed arithmetic mean of station skews was used to estimate the generalized skew coefficient for a northern cluster of Canadian streamgages that could not be estimated by the Minnesota generalized skew grid. A standard error for these stations was estimated as well. The final peak-flow frequency estimates for the LOW-RRB are based on station skews weighted with the estimated generalized skew values. Peak-flow frequency estimates were computed for exceedance probabilities of 0.667 (1.5 year), 0.50 (2 year), 0.20 ( 5 year), 0.10 (10 year), 0.04 (25 year), 0.02 (50 year), 0.01 (100 year), and 0.002 (500 year) and presented as percent annual exceedance probabilities of $66.7,50,20,10,4,2,1$, and 0.2 percent, respectively (table 1).

\section{Estimating Basin Characteristics}

Several basin characteristics were tested as possible explanatory variables in the regression equations. The selections of basin characteristics for this study were based on the results from previous studies in Canada; Minnesota; the nearby States of Iowa, North Dakota, South Dakota, and Wisconsin; and the availability of additional GIS data since the previous study (Lorenz and others, 2010) was completed. Drainage area, main-channel slope, basin slope, lake area, storage area (lake area and wetland area), precipitation, soil permeability, basin shape, and generalized mean annual runoff were all used as explanatory variables in previous studies.

Basin characteristics for the 49 streamgages for which peak-flow data were determined were estimated by compiling applicable digital datasets, converting to common formats, correcting anomalies, delineating gage watershed boundaries, and computing values for selected characteristics. Watersheds for Canadian and USGS streamgages were delineated using a GIS to analyze a hydrologically modified 10 -meter digital elevation model (DEM). The hydrologically modified DEM was created using three datasets: (1) a resampled 30-meter Provincial DEM (Ontario Ministry of Natural Resources and Forestry - Provincial Mapping Unit, 2013a; 2016) combined with a 10-meter DEM from the USGS National Elevation Dataset (2013); (2) Level 6 (12-digit) harmonized binational hydrologic unit boundaries (U.S. Geological Survey, 2013; Laitta, 2010) and lakeshed boundaries created by the Minnesota Lake Watershed Delineation Project (Solstad and Vaughn, 2007); and (3) a stream network compiled from harmonized USGS National Hydrography Data and Canadian National Hydro Network data and "DNR 24K Streams" from the 
MNDNR (2009) data deli. The MNDNR streams layer was modified to ensure correct directionality and checked to ensure that there were no streams crossing Level 6 (12 digit) hydrologic unit boundaries.

Arc Hydro, a geospatial hydrologic data structure and suite of GIS tools for managing water-resources data (Center for Research in Water Resources, 2003), was used to delineate streamgage watersheds and to compute eight streamgage watershed characteristics (table 1). Watershed polygons for each streamgage were overlaid with each of the characteristic layers, and a value (either mean or percent) was computed. Because of Arc Hydro requirements, all characteristic layers were in grid format; characteristic layers that were not in grid format when retrieved from the data source were converted to grid format. The drainage area (variable name DRNAREA, table 1) is the area, in square miles, defined by the watershed delineated for each streamgage and represents the entire area within the watershed, including any areas that might be considered noncontributing. The main-channel slope (variable name SLP1085FM) is defined as the slope of the main channel, in feet per mile, using the 10th and 85th percentile of the distance between the streamgage and the watershed boundary. The Arc Hydro tool identified the main channel, identified the 10- and 85-percentile points along the main channel, and extracted the elevation of the two percentile points. The difference in elevation between the points was divided by the main-channel length between the points to compute the slope in feet per mile.

Lake area (variable name LAKES; table 1), wetland area (variable name WETLANDS), and storage area (variable name STORAGE) of lakes and wetlands were computed from digital wetland data (Ontario Ministry of Natural Resources and Forestry - Provincial Mapping Unit, 2013b). The Ontario Ministry of Natural Resources and Forestry - Provincial Mapping Unit wetland data did not include some small lake basins; however, excluded small lake basins were considered inconsequential for most of the larger streamgage watersheds in Canada because of the minor percentage area that was not included. There were four streamgage watersheds (05PD017, 05PD019, 05PD023, and 05PD028) that had missing lake basins added manually using ArcGIS Online Imagery (2016) because of the large percentage of the total streamgage watershed area represented by the missing lakes.

On the U.S. side of the LOW-RRB, National Wetlands Inventory MNDNR digital data (1979-88) were used to generate the percentage of lakes, wetlands, and storage area (lakes and wetlands). Lake area included all National Wetland Inventory polygons classified as "lacustrine," wetland area included all polygons classified as "palustrine," and storage area included all polygons classified as "lacustrine," "palustrine," or "riverine." The percentage for each variable was computed as the total area of all extracted grid cells divided by the drainage area and multiplied by 100 . The variables in the regression equations have a constant of 1 added, because 0 values cannot be used in log-transformed datasets; For example, a computed value for percent lake area of 0 would be 1 when used in the regression equation. Mean annual precipitation (variable name
PRECIP), mean annual temperature (variable name TEMPERATURE), and mean annual runoff (variable name RUNOFF) 900-meter raster data represent the 1971 to 2000 period (McKay and others, 2012).

\section{Methods Used to Define Peak-Flow Hydrologic Regions}

Previous reports, including Jacques and Lorenz (1987) and Lorenz and others (1997), used an analysis of the pattern of residuals of statewide regressions to delineate initial peakflow hydrologic regions. Wolock and others (2004) developed a map of the entire United States that showed 20 different hydrologic landscape units. To develop the initial hydrologic regions, data for Minnesota reported in Wolock and others (2004) were extracted and reclustered into seven groups using the k-means algorithm of Hartigan and Wong (1979). The initial peak-flow hydrologic regions also are shown on figure 3 of Lorenz and others (2010). The regions were based on a subjective assessment of the association of the seven reclustered groups of hydrologic landscape units delineating generally along drainage boundaries. Region A represented one of the most heterogonous regions with low slope near the Red River, moderately sloped groups near the drainage boundary, and sandy soil groups between those areas. Region B is dominated by sandy soil groups with varying slope and flat areas.

Region C consists primarily of high and moderately sloped groups. The differences between the initial regions (fig. 1 in Lorenz and others, 2010) and the final regions (fig. 1 in this report) is the change of the high-slope areas in northern Minnesota from initial region $\mathrm{C}$ to final region B1, which represents the LOW-RRB. The streamgages used to develop the regression equations for the new region $\mathrm{B} 1$ are listed in table 1. Region B1 boundaries followed 8-digit hydrologic unit boundaries (U.S. Geological Survey, 2013; Laitta, 2010) so that the drainage area of a small stream will not overlap two regions, making interpretation easier for all streams.

\section{Development of Regional Regression Equations}

Multiple linear regression techniques were used to develop regression equations relating streamgage peak-flow frequencies to various basin characteristics for selected exceedance probabilities. Regression equations can be developed using ordinary-least-squares (OLS) and generalizedleast-squares (GLS) techniques. The OLS technique gives equal weight to peak flows at all streamgages, regardless of record length and the possible correlation among concurrent flows at different sites, and only provides a rough estimate of model error. The GLS technique accounts for unequal record length as well as cross correlation of concurrent flows at different stations and provides better estimates of the predictive 
accuracy of peak-flow estimates that are computed by the regression equations and nearly unbiased estimates of the variance of the underlying regression model error (Stedinger and Tasker, 1985). The USGS weighted-multiple-linear-regression computer program, WREG, was used to develop initial and final peak-flow frequency regression equations. For further detailed explanations about the OLS and GLS regression techniques, refer to the WREG user's guide (Eng and others, 2009; Stedinger and Tasker, 1985; Tasker and Stedinger, 1989).

The eight basin characteristics in table 1 were tested as explanatory variables in the regression analysis. Scatterplot matrices of the log-transformed (base 10) peak-flow discharges, log-transformed (base 10) explanatory variables, and untransformed explanatory variables were generated to evaluate whether log-transformation of the explanatory variables was needed and to check for correlation of the explanatory variables with peak flow.

To simplify the variable selection process, models were initially selected using a step-wise backward OLS regression. In addition, to reduce the potential complexity of the models and maintain similarity among the models for all the exceedance probabilities, only exceedance probabilities 0.50 and 0.01 were used for model selection. Step-wise backward regression was used to evaluate statistically significant basin characteristics to use as explanatory variables in the development of the final peak-flow frequency regression models. The final variables selected for exceedance probabilities 0.50 and 0.01 were the same, and those variables also were used for exceedance probabilities of $0.667,0.20,0.10,0.04,0.02$, and 0.002 . The resulting OLS regression models were restricted to two explanatory variables using a 5-percent (0.05) significance level, selecting models with the largest coefficient of determination $\left(R^{2}\right)$ and examining scatterplots of residuals compared to fitted values to verify randomness for each of the selected explanatory variables.

The final explanatory variables and associated transformations determined in the OLS regression models were then used to determine the GLS regression models. Streamgages that were "flagged" by the WREG program as having large influence or leverage were further examined for elimination. Influence is a measure of how strongly the values for a streamgage influence the estimated regression parameters. Leverage is a measure of how much the values of explanatory variables at a streamgage vary from values of those variables at all other streamgages. Residual scatterplots as compared to fitted values and explanatory variables also were examined to determine if "flagged" streamgages with large influence and leverage were isolated hydrologic outliers and could be removed from the analysis.

Final GLS regional regression equations were selected based on minimizing values of the standard model error (SME), the standard error of prediction $\left(S_{\mathrm{p}}\right)$, and the average variance of prediction (AVP), and maximizing values of the pseudo $R^{2}$ (table 3; Eng and others, 2009). The performance metrics pseudo $R^{2}$ and SME indicate how well the equations perform on the streamgages used in the regression analyses. The $S_{\mathrm{p}}$ and AVP are measures of the accuracy with which GLS regression models can predict AEPDs at ungaged sites. SME measures the error of the model itself and does not include sampling error. The $S_{\mathrm{p}}$ represents the sum of the model error and the sampling error. The $S_{\mathrm{p}}$ is the square root of the GLS AVP (Tasker and Stedinger, 1989; Eng and others, 2009). The AVP is a measure of the average accuracy of prediction for all sites used in the development of the regression model and assumes that the explanatory variables for the streamgages included in the regression analysis are representative of all streamgages in the region (Verdi and Dixon, 2011). The pseudo $R^{2}$ is a measure of the percentage of the variation explained by the basin characteristics (explanatory variables) included in the model. The characteristics pre-determined by OLS regression and used in the final regional regression equations are drainage area (DRNAREA) and percent area of lakes (LAKES). The $S_{\mathrm{p}}$ for the various exceedance probabilities ranged from 33.9 to 63.6 percent. The pseudo $R^{2}$ ranged from 93.4 to 98.3 percent and the SME ranged from 32.1 to 59.2 percent.

Table 3. Regional regression equations for peak-flow frequency estimates in the Lake of the Woods-Rainy River Basin.

$\left[S_{\mathrm{p}}\right.$, average standard error of prediction, in percent; $R^{2}$, pseudo coefficient of determination, in percent; SME, standard model error, in percent; AVP, average variance of prediction, in log units; $Q_{\times \%}$, peak flow for $\times$ percent of annual exceedance probability; DRNAREA, drainage area, in square miles; LAKES, percent lakes, percentage of basin drainage area that are lakes; $\leq$, less than or equal to]

\begin{tabular}{|c|c|c|c|c|c|}
\hline Regression equation & $\begin{array}{l}\text { Range of explanatory variables } \\
\text { for all regression equations }\end{array}$ & $S_{\mathrm{p}}$ & $R^{2}$ & SME & AVP \\
\hline $\log Q_{66.7 \%}=1.126+0.815 \times \log ($ DRNAREA $)-0.020 \times($ LAKES $)$ & \multirow{8}{*}{$\begin{array}{c}0.037 \leq \text { DRNAREA } \leq 1840 ; 0 \leq \\
\text { LAKES } \leq 22.3\end{array}$} & 34.1 & 98.3 & 32.2 & 0.021 \\
\hline $\log Q_{50 \%}=1.253+0.812 \times \log ($ DRNAREA $)-0.022 \times($ LAKES $)$ & & 33.9 & 98.3 & 32.1 & 0.020 \\
\hline $\log Q_{20 \%}=1.510+0.798 \times \log ($ DRNAREA $)-0.026 \times($ LAKES $)$ & & 38.3 & 97.8 & 36.1 & 0.026 \\
\hline $\log Q_{10 \%}=1.649+0.786 \times \log ($ DRNAREA $)-0.028 \times($ LAKES $)$ & & 42.2 & 97.3 & 39.8 & 0.031 \\
\hline $\log Q_{4 \%}=1.795+0.773 \times \log ($ DRNAREA $)-0.030 \times($ LAKES $)$ & & 47.6 & 96.5 & 44.7 & 0.039 \\
\hline $\log Q_{2 \%}=1.891+0.763 \times \log ($ DRNAREA $)-0.032 \times($ LAKES $)$ & & 50.8 & 96.0 & 47.6 & 0.043 \\
\hline $\log Q_{1 \%}=1.975+0.754 \times \log ($ DRNAREA $)-0.033 \times($ LAKES $)$ & & 55.5 & 95.1 & 51.8 & 0.051 \\
\hline $\log Q_{02 \%}=2.146+0.734 \times \log ($ DRNAREA $)-0.035 \times($ LAKES $)$ & & 63.6 & 93.4 & 59.2 & 0.064 \\
\hline
\end{tabular}




\section{Accuracy and Limitations of the Regional Regression Equations}

Regression equations presented in table 3 are empirical models that relate AEPDs to a particular dataset of physical and climatic basin attributes. These equations must be interpreted and applied within the limits of the data and with the understanding that the results are best-fit estimates with an associated variance. The regression equations have an associated measure of quality indicating how well the predicted values represent the true values, and a reported uncertainty. The following limitations should be considered when using the regression equations to compute peak-flow frequencies for LOW-RRB streams: (1) the streamgages should be located in watersheds that are not substantially affected by urbanization or regulation, (2) the explanatory variables should be computed using the same GIS techniques that were used to develop the regression equations, and (3) the explanatory variables should stay within the range of the data used to develop the regression equations (table 1).

\section{Web Application for Solving Regional Regression Equations}

The LOW-RRB StreamStats web application (https:// streamstats.usgs.gov/ss/) will incorporate the new peakflow frequency regression equations and provide peak-flow frequency estimates for most unregulated sites in the basin. The web application will include (1) a mapping tool to specify a location on a stream where peak-flow statistics are desired; (2) a database that includes peak-flow frequency statistics, hydrologic characteristics, location, and descriptive information for all USGS and Canadian streamgages used in this study; and (3) an automated GIS procedure that measures the required basin characteristics and solves the regression equations to estimate peak-flow statistics for user-selected sites. Users should be cautious when selecting sites with small drainage areas generally less than 1 square mile in Canada because of the possibility that there may be missing lakes that will affect predicted peak flows.

\section{Application of Regional Regression Equations}

The developed regression equations can be used to provide peak-flow frequency estimates for sites on ungaged or gaged streams. Peak-flow frequency estimates for streamgages may be improved by computing a weighted-average value of two independent estimates: the at-site log-Pearson Type III frequency curve estimate and the appropriate regression equation estimate. By weighting each estimate with an appropriate weighting factor, the resulting weighted-average value will represent an improved estimate (Interagency Advisory
Committee on Water Data, 1982). Peak-flow frequency estimates can be computed using the appropriate regression equation for an ungaged site on a stream without a streamgage.

\section{Estimating the Weighted Peak-Flow Frequency for a Streamgage}

Two estimates of peak-flow frequency for a streamgage are available: one from the at-site log-Pearson Type III frequency curve and the other from the appropriate peak-flow frequency regression equation developed in this study. A theoretically improved estimate can be calculated if the individual estimates are independent and the variances of the individual estimates can be determined. If the independent estimates are weighted inversely proportional to their respective variances, then the variance of the weighted-average estimate will be less than the variances associated with each individual estimate (Tasker, 1975; Interagency Advisory Committee on Water Data, 1982).

For a particular exceedance probability, the variance associated with the at-site frequency-curve estimate can be computed using an expression for the asymptotic variance developed by Cohn and others (2001) and implemented in the Weighted Independent Estimates program (Berenbrock and Cohn, 2008). The magnitude of the variance associated with the at-site frequency-curve estimate is dependent on the length of record; the mean, standard deviation, and skew of the fitted log-Pearson Type III frequency curve; and the accuracy of the method used to determine the generalized skew (Gotvald and others, 2009).

For a selected exceedance probability, the variance associated with the appropriate regression equation is the AVP, which can be computed from the $S_{\mathrm{p}}$ using the following equation:

$$
A V P=\frac{\ln \left\{\left(\frac{S_{p}}{100}\right)^{2}+1\right\}}{(\ln 10)^{2}}
$$

An alternative variance associated with the regression equation can be determined for each streamgage, although the average variance of prediction from all streamgages is used in this study. Using the variances from the two independent peakflow frequency estimates, the weighted-average peak-flow frequency estimate is computed using the following equation (Gotvald and others, 2009):

$$
\log Q_{\% g w}=\frac{V_{\% g r} \times \log Q_{\% g s}+V_{\% g s} \times \log Q_{\% g r}}{V_{\% g s}+V_{\% g r}}
$$

where

$Q_{\% \text { ww }} \quad$ is the peak-flow estimate for selected exceedance probability at a streamgage, weighted-average value, in cubic feet per second; 
$Q_{\% g s} \quad$ is the peak-flow estimate for selected exceedance probability at a streamgage, value from the station log-Pearson Type III frequency curve, in cubic feet per second;

$Q_{\% g r} \quad$ is the peak-flow estimate for selected exceedance probability at a streamgage, value from the appropriate regression equation, in cubic feet per second;

$V_{\% \text { ogs }} \quad$ is the variance of prediction of a peakflow estimate for selected exceedance probability at a streamgage, value from station log-Pearson Type III frequency curve, in logarithm units; and

$V_{\% g r} \quad$ is the average variance of prediction of a peak-flow estimate for selected exceedance probability at a streamgage, value associated with the appropriate regression equation, in logarithm units.

\section{Estimating the Peak-Flow Frequency for an Ungaged Site}

The procedure for estimating peak-flow frequency for selected exceedance probabilities for a specific ungaged site depends on whether the site is located near a streamgage on the same stream or is on an ungaged stream. For an ungaged site near a streamgage on the same stream, the drainage-area ratio method may be used. The drainage-area ratio method assumes that the streamflow for a site of interest can be estimated by multiplying the ratio of the drainage area for the site of interest and the drainage area for a nearby streamgage by the log-Pearson Type III peak flow estimate for the nearby streamgage. Generally, the method should be used when the drainage area for an ungaged site is within 50 percent of the drainage area for a streamgage site (Ries and Dillow, 2006). For an ungaged site on an ungaged stream, the regional regression equations developed for this study should be used.

\section{Regression-Weighted and Area-Weighted Estimates for an Ungaged Site on a Gaged Stream}

For an ungaged site on a stream with a streamgage that has 10 or more years of peak-flow record, the peak-flow frequency estimate from the appropriate regression equation for the ungaged site can be combined with the weighted-average peak-flow frequency estimate and regression equation peakflow frequency estimate from the nearby streamgage to produce an improved estimate. Sauer (1974) and Verdi and Dixon (2011) presented the following regression-weighted equation to improve the peak-flow frequency estimate for an ungaged site on a stream with a streamgage:

$$
Q_{\% \text { } u w}=\left[\left(\frac{2\left|A_{g}-A_{u}\right|}{A_{g}}\right)+\left(\left(1-\frac{2\left|A_{g}-A_{u}\right|}{A_{g}}\right) \frac{Q_{\% g w}}{Q_{\% g r}}\right)\right] Q_{\% u r}
$$

where

$Q_{\% w w} \quad$ is the peak-flow estimate for selected exceedance probability at an ungaged site, weighted-average value, in cubic feet per second;

$Q_{\% g w} \quad$ is the peak-flow estimate for selected exceedance probability at a streamgage, weighted-average value, in cubic feet per second;

$Q_{\% \mathrm{gr}} \quad$ is the peak-flow estimate for selected exceedance probability at a streamgage, value from the appropriate regression equation, in cubic feet per second;

$Q_{\% u r} \quad$ is the peak-flow estimate for selected exceedance probability at an ungaged site, value from the appropriate regression equation, in cubic feet per second;

$A_{g} \quad$ is the drainage area associated with a streamgage, in square miles; and

$A_{u} \quad$ is the drainage area associated with an ungaged site, in square miles.

The following simpler area-weighted equation can be used as an alternative:

$$
Q_{\% \text { ow }}=Q_{\% \text { ogw }}\left(A_{u} / A_{g}\right)^{b}
$$

where

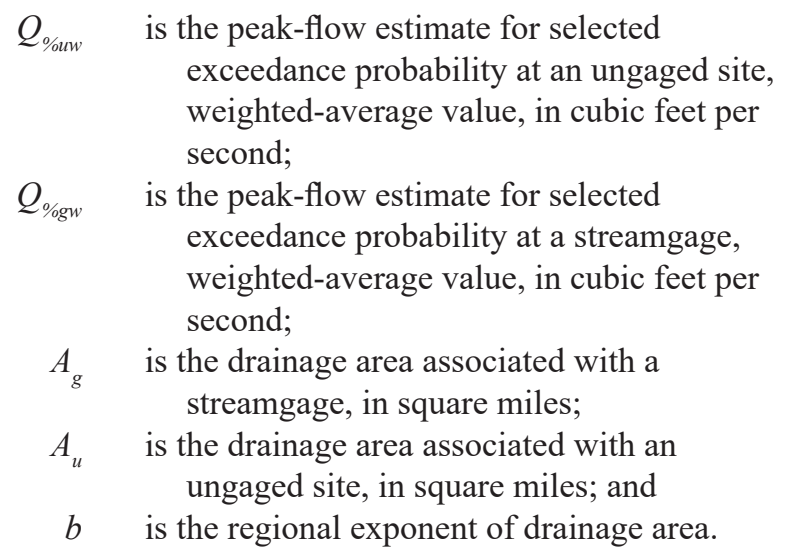

The regional exponents $(b$, table 4$)$ were derived from WREG using a GLS analysis of log-transformed (base-10) of peak-flow discharges and drainage area. The exponents range from 0.702 to 0.806 . The exponent $b$ for a selected exceedance probability is recommended for use to obtain an area-weighted peak-flow frequency estimate at an ungaged site on a gaged stream. An average exponent $b$ for the range of exceedance probabilities $(0.762)$ can be used in equation 6 for each of the peak-flow exceedance frequency estimates as well for a more general peak-flow frequency estimate. 
Table 4. Regional exponent determined from regional regression of log-transformed (base-10) drainage area for an area-weighted ratio method to estimate peakflow frequency for an ungaged site on a gaged stream in Lake of the Woods-Rainy River Basin.

$[b$, regional exponent of drainage area used in equation 6]

\begin{tabular}{cc}
\hline $\begin{array}{c}\text { Annual exceedance } \\
\text { probability }\end{array}$ & Exponent $\boldsymbol{b}$ \\
\hline 0.667 & 0.806 \\
0.50 & 0.804 \\
0.20 & 0.786 \\
0.10 & 0.771 \\
0.04 & 0.754 \\
0.02 & 0.741 \\
0.01 & 0.729 \\
0.002 & 0.702 \\
Average & $\mathbf{0 . 7 6 2}$ \\
\hline
\end{tabular}

If the drainage area associated with the ungaged site is between 50 and 150 percent of the area associated with the streamgage, equations 5 and 6 are applicable. If the drainage area associated with the ungaged site is less than 50 or greater than 150 percent of the area associated with the streamgage, then no weighting adjustment is applied to the peak-flow frequency regression estimate for the ungaged site.

\section{Additional Considerations for Applying Peak- Flow Estimation Techniques}

The accuracy of a statistically derived equation is measured by the closeness of the estimated value to the true value. Regression analyses give an unbiased estimate of the true value and statistics to assess the accuracy of the estimate. The $S_{\mathrm{p}}$ is an estimate of the accuracy of the result obtained by applying a regression equation to a set of explanatory variables that accounts for the regression error and the uncertainty of the coefficients of the explanatory variables (Riggs, 1968). The $S_{\mathrm{p}}$ is a function of the basin characteristics at a site and therefore varies from site to site.

The 90-percent prediction interval is another measure of the uncertainty of the estimated value. The 90-percent prediction interval is calculated by multiplying or dividing the estimated value by a factor that is dependent on the mean standard errors of prediction and the critical value of the t-distribution for a particular model. The information necessary to compute prediction intervals is included in the equations for LOWRRB in the National Streamflow Statistics program (U.S. Geological Survey, 2007).

The accuracy of the estimating equation is limited by the uncertainty of the input data. Uncertainty has two components: (1) variance, a measure of the random variation about the true value; and (2) bias, the consistent deviation of the value from the true value. How well the peak-flow estimates from the log-Pearson Type III analysis of the recorded annual peak flows predicts the actual population of peak flows depends on the sample size, the accuracy of each recorded peak value, and how well the log-Pearson Type III distribution fits the actual distribution (Interagency Advisory Committee on Water Data, 1982).

The accuracy of the regression estimate is affected by errors in the explanatory variables. Errors in quantifying the drainage-basin characteristics result from an inability to completely describe the effect of those characteristics. For example, the effects of wetlands and lakes depend on their size and location in the basin and in the stream channels, but the explanatory variable STORAGE is simply expressed as a percentage of total drainage area without regard to size or location.

Bias of a peak-flow estimate can result from systematic errors in the computation of the annual peak flows and is the result of collecting peak-flow data during a period that does not reflect the long-term population of peak flows. The derived peak-flow statistics reflect those periods, which may not be representative of the long-term conditions such as increasing or decreasing trends in streamflow due to climate or anthropogenic changes. This was not addressed in this study, but future peak-flow analyses in this area would benefit from regional trend studies for Minnesota and nearby States.

The accuracy of an estimate made using the techniques presented in this report also can be affected by the user. Each user will make certain decisions based on their best judgment about the actual outline of the drainage basin, the path of the main channel, interpolation of generalized runoff, and the source of lake and wetland data. These individual sources of error can be reduced by use of shared computer datasets that are updated as improved information becomes available and the use of a GIS that provides consistent results.

The accuracy of peak-flow estimates made at sites immediately downstream from a lake or ponded area where the storage capacity could substantially alter peak-flow characteristics can be improved by a routing adjustment. In such places, the frequency relations could be used as an aid in developing a hydrograph of the inflow and then a simulation of that flow can be routed through the lake to determine the peak of the outflow. The values of the explanatory variables used in this analysis were all computed from consistent datasets using a GIS. Careful analysis using the best available topographic maps should provide accurate estimates of drainage area, main-channel slope, percent lake, and percent storage (percentage watershed area covered by lakes and wetlands). Regression equations are less valid in basins that are outside of the range of drainage areas and percent lakes used in the dataset (table 1). Extrapolation of regression estimates outside these conditions have greater uncertainty. The National Streamflow Statistics program will issue a warning message if the estimated peak flow is an extrapolation beyond the data on which the estimation is based. 


\section{Summary}

A binational study was initiated to update statistical equations that are used to estimate the magnitude and frequency of peak flows on streams in Manitoba and Ontario, Canada, and Minnesota that are contained within the binational Lake of the Woods-Rainy River Basin upstream from Kenora, Ontario, Canada. Hydraulic engineers use peak streamflow data to inform designs of bridges, culverts, and dams, and water managers use peak streamflow data to inform regulation and planning activities. However, long-term streamflow measurements are available at few locations along the more than 20,000 miles of stream/ditch networks within the binational Lake of the Woods-Rainy River Basin upstream from Kenora, Ontario, Canada. Therefore, the U.S. Geological Survey conducted a binational study in cooperation with the International Joint Commission and the Minnesota Department of Transportation to update statistical equations that estimate the magnitude and frequency of peak streamflows at ungaged sites.

Estimates of peak-flow magnitudes for 66.7-, 50-, 20-, 10-, 4-, 2-, 1-, and 0.2-percent annual exceedance probabilities equivalent to annual flood-frequency recurrence intervals of 1.5-, 2-, 5-, 10-, 25-, 50-, 100-, and 500-year recurrence intervals, respectively, are presented for 49 streamgages based on data collected through September 30, 2013 (U.S. Geological Survey water year 2013). Canadian maximum instantaneous peak-flow data were converted from a calendar year to a water year (October 1 to September 30) and where the annual maximum instantaneous peak-flow value was not available in HYDAT, the Sangal method was applied to known average daily flow values to estimate an annual maximum instantaneous peak-flow value.

Geographic information system software was used to calculate eight physical characteristics investigated as potential explanatory variables in regression analyses. A total of eight regression equations were developed in this study to calculate peak-flow frequency statistics for ungaged locations within the study area. Peak-flow frequency information was subsequently used in regression analyses to develop equations relating peak flows for selected recurrence intervals to various physical and climatic characteristics. The statistically derived techniques can be used to estimate peak flow on ungaged streams smaller than 1,840 square miles in the study area.

The study area includes 49 streamgages located in the binational Lake of the Woods-Rainy River Basin upstream from Kenora, Ontario, Canada, and is represented by southern portions of the Canadian Provinces of Manitoba (2 percent) and Ontario (56 percent) and the most northern portion of the U.S. State of Minnesota (42 percent). The study area's new hydrologic region $\mathrm{B} 1$ was previously represented by three hydrologic regions that were developed by studies in the U.S. State of Minnesota and another in the Canadian Province of Ontario. The two Minnesota regions A and B were developed using the multiple regression method and hydrologic landscape units. The Ontario region A was developed using the multiple regression method and standardized residuals from 100-year recurrence intervals. Most of region B1 is represented by surficial bedrock overlain with greater than 30,000 lakes and wetlands. It includes high, moderate, and low slopes in the very southwest portion of the region.

The final regression equations were chosen based on minimizing values of the standard model error and the standard error of prediction, maximizing values of the pseudo coefficient of determination, and examination of regression residuals. Updated peak-flow frequency data and peak-flow regional regression frequency data used in the study are provided. Methods were presented for determining weighted peak-flow frequency data for streamgages and ungaged sites. The procedure for estimating peak-flow frequency for selected exceedance probabilities for a specific ungaged site depends on whether the site is located near a streamgage on the same stream or is on an ungaged stream. For an ungaged site near a streamgage on the same stream, the drainage-area ratio method can be applied. For an ungaged site on an ungaged stream, the regional regression equations developed for this study should be used.

Equations developed in this study apply only to stream locations where flows are not substantially affected by regulation, diversion, or urbanization. All equations presented in this study will be incorporated into StreamStats, a web-based geographic information system tool developed by U.S. Geological Survey. StreamStats allows users to obtain streamflow statistics, basin characteristics, and other information for userselected locations on streams through an interactive map.

\section{References}

Arneson, L.A., Zevenbergen, L.W., Lagasse, P.F., and Clopper, P.E., 2012, Evaluating scour at bridges (5th ed.): Federal Highway Administration, Publication No. FHWAHIF-12-003, Hydraulic Engineering Circular No. 18, 340 p., accessed March 15, 2013, at http://www.fhwa.dot.gov/ engineering/hydraulics/pubs/hif12003.pdf.

Berenbrock, C., and Cohn, T., 2008, Weighted independent estimates, WIE: U.S. Geological Survey software program, accessed October 1, 2009, at http://water.usgs.gov/usgs/ osw/FreqReg/.

Center for Research in Water Resources, 2003, Arc Hydro Online Support System: accessed August 2008, at http:// www.crwr.utexas.edu/giswr/hydro/ArcHOSS/index.Cfm. 
Cohn, T.A., England, J.F., Berenbrock, C.E., Mason, R.R., Stedinger, J.R., and Lamontagne, J.R., 2013, A generalized Grubbs-Beck test statistic for detecting multiple potentially influential low outliers in flood series: Water Resources Research, v. 49, no. 8, p. 5047-5058. [Also available at https://doi.org/10.1002/wrcr.20392.]

Cohn, T.A., Lane, W.L., and Stedinger, J.R., 2001, Confidence intervals for Expected Moments Algorithm flood quantile estimates: Water Resources Research, v. 37, no. 6, p. 1695-1706. [Also available at https://doi. org/10.1029/2001WR900016.]

DigitalGlobe, 2016, ArcGIS Online Imagery, 2016: Esri, DigitalGlobe, accessed March 2016.

Eash, D.A., Barnes, K.K., and Veilleux, A.G., 2013, Methods for estimating annual exceedance-probability discharges for streams in Iowa, based on data through water year 2010: U.S. Geological Survey Scientific Investigations Report 2013-5086, 63 p. with appendix.

Eng, K., Chen, Y.-Y., and Kiang, J.E., 2009, User's guide to the weighted-multiple-linear-regression program (WREG version 1.0): U.S. Geological Survey Techniques and Methods, book 4, chap. A8, 21 p. [Also available at http://pubs. usgs.gov/tm/tm4a8.]

England, J.F., Jr., Cohn, T.A., Faber, B.A., Stedinger, J.R., Thomas, W.O., Jr., Veilleux, A.G., Kiang, J.E., and Mason, R.R., Jr., 2018, Guidelines for determining flood flow frequency-Bulletin 17C: U.S. Geological Survey Techniques and Methods, book 4, chap. B5, 148 p., [Also available at https://doi.org/10.3133/tm4B5.]

Federal Emergency Management Agency, 2002, National Flood Insurance Program-Program description: 37 p. [Also available at https:/www.fema.gov/media-librarydata/20130726-1447-20490-2156/nfipdescrip_1_.pdf.]

Fischer, E.E., 1995, Potential-scour assessments and estimates of maximum scour at selected bridges in Iowa: U.S. Geological Survey Water-Resources Investigations Report 95-4051, 75 p.

Flynn, K.M., Kirby, W.H., Mason, R., and Cohn, T.A., 2006, Estimating magnitude and frequency of floods using the PeakFQ program: U.S. Geological Survey Fact Sheet 2006-3143, 2 p.

Gotvald, A.J., Feaster, T.D., and Weaver, J.C., 2009, Magnitude and frequency of rural floods in the southeastern United States, 2006-Volume 1, Georgia: U.S. Geological Survey Scientific Investigations Report 2009-5043, 120 p.
Grubbs, F.E., and Beck, G., 1972, Extension of sample sizes and percentage points for significance tests of outlying observations: Technometrics, v. 10, no. 4, p. 211-219. [Also available at https://doi.org/10.1080/00401706.1972.104889 81.]

Guetzkow, L.C., 1977, Techniques for estimating magnitude and frequency of floods in Minnesota: U.S. Geological Survey Water-Resources Investigations Report 77-31, 33 p.

Hartigan, J.A., and Wong, M.A., 1979, A k-means clustering algorithm: Applied Statistics, v. 28, no. 1, p. 100-108. [Also available at https://doi.org/10.2307/2346830.]

Interagency Advisory Committee on Water Data, 1982, Guidelines for determining flood-flow frequency: Reston, VA., U.S. Geological Survey, Bulletin 17B of the Hydrology Subcommittee, Office of Water Data Coordination, 183 p. [Also available at https://water.usgs.gov/osw/bulletin17b/ bulletin_17B.html.]

International Lake of the Woods Basin Water Quality Plan of Study Team, 2014, International Lake of the Woods Basin water quality plan of study - Covering the Rainy-Lake of the Woods watershed: 141 p. [Also available at http://ijc. org/files/tinymce/uploaded/lwbwqpos/LOWBPOS $\% 20$ Nov\%2012\%202014.pdf.]

International Watersheds Initiative, 2013, Mandate: accessed January 2017 at www.ijc.org/conseil_board/watershed/en/ watershed_mandate_mandat.htm.

Jacques, J.E., and Lorenz, D.L., 1987, Techniques for estimating the magnitude and frequency of floods in Minnesota: U.S. Geological Survey Water-Resources Investigations Report 87-4170, 48 p.

Kessler, E.W., Lorenz, D.L., and Sanocki, C.A., 2013, Methods and results of peak-flow frequency analyses for streamgages in and bordering Minnesota, through water year 2011: U.S. Geological Survey Scientific Investigations Report 2013-5110, 43 p. [Also available at http://pubs.usgs. gov/sir/2013/5110/.]

Laitta, M., 2010, IJC, Canada-U.S. transboundary hydrographic data harmonization efforts gain momentum: International Joint Commission, accessed January 2017 at http:// www.ijc.org/rel/boards/watershed/Canada-US_Hydro_ Harmonization_e.pdf.

Lake of the Woods SWCD, 2016, Lake of the Woods total maximum daily load (TMDL) study: 4 p., accessed June 2017 at http://lakeofthewoodsswcd.org/projects/lowtmdl/ FAQ.pdf. 
Lorenz, D.L., 1997, Generalized skew coefficients for floodfrequency analysis in Minnesota: U.S. Geological Survey Water-Resources Investigations Report 97-4089, 15 p. [Also available at https://pubs.er.usgs.gov/publication/ wri974089.]

Lorenz, D.L., Carlson, G.H., and Sanocki, C.A., 1997, Techniques for estimating peak flow on small streams in Minnesota: U.S. Geological Survey Water-Resources Investigations Report 97-4249, 42 p. [Also available at https://pubs. er.usgs.gov/publication/wri974249.]

Lorenz, D.L., Sanocki, C.A., and Kocian, M.J., 2010, Techniques for estimating the magnitude and frequency of peak flows on small streams in Minnesota based on data through water year 2005: U.S. Geological Survey Scientific Investigations Report 2009-5250, 54 p. [Also available at https:// pubs.er.usgs.gov/publication/sir20095250.]

Lorenz, D.L., and Ziegeweid, J.R., 2016, Methods to estimate historical daily streamflow for ungaged stream locations in Minnesota: U.S. Geological Survey Scientific Investigations Report 2015-5181, 18 p., accessed July 2017 at https:// pubs.er.usgs.gov/publication/sir20155181.

McKay, L., Bondelid, T., Dewald, T., Johnston, J., Moore, R., and Rea, A., 2012, NHDPlus Version 2-User Guide: U.S. Environmental Protection Agency, 180 p. [Also available at https://s3.amazonaws.com/nhdplus/NHDPlusV21/ Documentation/NHDPlusV2_User_Guide.pdf.]

Minnesota Department of Natural Resources, 2009, Data deli: accessed February 2009 at http://deli.dnr.state.mn.us.

Minnesota Department of Natural Resources, 1979-1988, National Wetlands Inventory-Statewide Raster 19791988: accessed December 2016 at https://gisdata.mn.gov/ dataset/water-nat-wetlands-inventory.

Moin, S., and Shaw, M., 1985, Canada/Ontario Flood Damage Reduction Program-Regional flood frequency analysis for Ontario streams, Volume 1-Single station analysis and index method: Ontario, Canada, Environment Canada, $126 \mathrm{p}$.

Ontario Ministry of Natural Resources and Forestry, 2013, Ontario Flow Assessment Tool III user guide: 56 p., accessed January 2016 at https:/www.ontario.ca/page/ ontario-flow-assessment-tool-guide.

Ontario Ministry of Natural Resources and Forestry - Provincial Mapping Unit, 2013a, Provincial Digital Elevation Model: accessed June 2015 at https:/www.javacoeapp.lrc. gov.on.ca/geonetwork/srv/en/main.home?uuid=012e363222a2-49d8-bbaf-ad8fbc0d0ceb.
Ontario Ministry of Natural Resources and Forestry - Provincial Mapping Unit, 2013b, Wetland: accessed June 2015 at https:/www.javacoeapp.lrc.gov.on.ca/geonetwork/ srv/en/main.home?uuid=04e466a9-7731-438c-a37a38fde98202b7.

Ontario Ministry of Natural Resources and Forestry - Provincial Mapping Unit, 2016, Provincial Digital Elevation Model technical specification, Version 1617.1: 26 p.

Patterson, J.L., and Gamble, G.R., 1968, Magnitude and frequency of floods in the United States, Part 5: U.S. Geological Survey Water-Supply Paper 1678, 546 p.

Prior, C.H., 1949, Magnitude and frequency of floods in Minnesota: St. Paul, Minnesota Department of Conservation, Division of Waters Bulletin 1, 128 p.

Prior, C.H., and Hess, J.H., 1961, Floods in Minnesota-Magnitude and frequency: St. Paul, Minnesota Department of Conservation, Division of Waters Bulletin 12, 142 p.

Ries, K.G., III, and Dillow, J.J.A., 2006, Magnitude and frequency of floods on nontidal streams in Delaware: U.S. Geological Survey Scientific Investigations Report 2006-5146, 59 p.

Ries, K.G., III, Newson J.K., Smith, M.J., Guthrie, J.D., Steeves, P.A., Haluska, T.L., Kolb, K.R., Thompson, R.F., Santoro, R.D., and Vraga, H.W., 2017, StreamStats, version 4: U.S. Geological Survey Fact Sheet 2017-3046, 4 p. [Also available at https://doi.org/10.3133/fs20173046.] [Supersedes USGS Fact Sheet 2008-3067.]

Riggs, H.C., 1968, Regional analyses of streamflow characteristics: U.S. Geological Survey Techniques of WaterResources Investigations, book 4, chap. B3, 14 p., accessed June 2015 at https://pubs.usgs.gov/twri/twri4b3/pdf/twri_4B3_a.pdf.

Sando, S.K., Driscoll, D.G., and Parrett, C., 2008, Peak-flow frequency estimates based on data through water year 2001 for selected streamflow-gaging stations in South Dakota: U.S. Geological Survey Scientific Investigations Report 2008-5104, 367 p.

Sangal, B.P., 1983, Practical method of estimating peak flow: Journal of Hydraulic Engineering, v. 109, no. 4, p. 549-563, accessed January 16, 2018, at https://doi.org/10.1061/ (ASCE)0733-9429(1983)109:4(549).

Sauer, V.B., 1974, Flood characteristics of Oklahoma streams-Techniques for calculating magnitude and frequency of floods in Oklahoma, with compilations of flood data through 1971: U.S. Geological Survey WaterResources Investigation Report 73-52, 46 p. 
Sehgal, K., 2016, A unified Ontario flood method-Regional flood frequency analysis on Ontario streams using multiple regression: Department of Civil Engineering University of Toronto, Master Thesis, 147 p., accessed January 16, 2018, at http://hdl.handle.net/1807/76843.

Solstad, J., and Vaughn, S., 2007, The Minnesota Lake Watershed Delineation (Lakeshed) Project: Minnesota Department of Natural Resources, accessed August 2007 at http:// www.dnr.state.mn.us/watersheds/lakeshed_project.html.

Stedinger, J.R., and Tasker, G.D., 1985, Regional hydrologic analysis 1 - Ordinary, weighted, and generalized least squares compared: Water Resources Research, v. 21, no. 9, p. 1421-1432. [Also available at https://doi.org/10.1029/ WR021i009p01421.]

Tasker, G.D., 1975, Combining estimates of low-flow characteristics of streams in Massachusetts and Rhode Island: Journal of Research of the U.S. Geological Survey, v. 3, no. 1, p. 107-112.

Tasker, G.D., and Stedinger, J.R., 1989, An operational GLS model for hydrologic regression: Journal of Hydrology (Amsterdam), v. 111, nos. 1-4, p. 361-375. [Also available at https://doi.org/10.1016/0022-1694(89)90268-0.]

U.S. Geological Survey, 2007, National streamflow statistics program-Estimating high and low streamflow statistics for ungaged sites: U.S. Geological Survey Fact Sheet 2007-3010, 2 p., accessed June 2015 at http://pubs.usgs. gov/fs/2007/3110.

U.S. Geological Survey, 2013, National Elevation Dataset, 1/3 arc second: accessed January 2013 at https://viewer. nationalmap.gov/.

U.S. Geological Survey, 2018, National Water Information System-Web interface: accessed January 2016 at https:// doi.org/10.5066/F7P55KJN.

Veilleux, A.G., Cohn, T.A., Flynn, K.M., Mason, R.R., Jr., and Hummel, P.R., 2014, Estimating magnitude and frequency of floods using the PeakFQ 7.0 program: U.S. Geological Survey Fact Sheet 2013-3108, 2 p., accessed January 2015 at http://pubs.usgs.gov/fs/2013/3108/.

Verdi, R.J., and Dixon, J.F., 2011, Magnitude and frequency of floods for rural streams in Florida, 2006: U.S. Geological Survey Scientific Investigations Report 2011-5034, 69 p., $1 \mathrm{pl}$.

Walker, J.F., and Krug, W.R., 2003, Flood-frequency characteristics of Wisconsin streams: U.S. Geological Survey Water-Resources Investigations Report 2003-4250, 16 p., accessed January 2016 at https://pubs.er.usgs.gov/publication/wri034250.
Water Survey of Canada, 2016, Twenty fourth release of HYDAT archived hydrometric database: accessed July 2016 at http://www.ec.gc.ca/rhc-wsc.

Wiitala, S.W., 1965, Magnitude and frequency of floods in the United States, Part 4: U.S. Geological Survey Water-Supply Paper 1677, $357 \mathrm{p}$.

Williams-Sether, T., 2015, Regional regression equations to estimate peak-flow frequency at sites in North Dakota using data through 2009: U.S. Geological Survey Scientific Investigations Report 2015-5096, 12 p., accessed January 2017 at https://doi.org/10.3133/sir20155096.

Winter, T.C., 2001, The concept of hydrologic landscapes: Journal of the American Water Resources Association, v. 37, no. 2, p. 335-349, accessed January 2017 at https://doi. org/10.1111/j.1752-1688.2001.tb00973.x.

Wolock, D.M., Winter, T.C., and McMahon, G., 2004, Delineation and evaluation of hydrologic-landscape regions in the United States using geographic information system tools and multivariate statistical analyses: Environmental Management, v. 34, no. S1, suppl. 1, p. S71-S88, accessed January 2017 at https://doi.org/10.1007/s00267-003-5077-9.

Ziegeweid, J.R., Lorenz, D.L., Sanocki, C.A., and Czuba, C.R., 2015, Methods for estimating flow-duration curve and low-flow frequency statistics for ungaged locations on small streams in Minnesota: U.S. Geological Survey Scientific Investigations Report 2015-5170, 23 p., accessed January 2016 at http://dx.doi.org/10.3133/sir20155170.

Ziegeweid, J.R., Silliker, R.J., Densmore, B.K., and Krahulik, Justin, 2016, Network Global Navigation Satellite System survey to harmonize water-surface elevation data for the Rainy River Basin: U.S. Geological Survey Scientific Investigations Report 2016-5109, 20 p., accessed June 2017 at http://dx.doi.org/10.3133/sir20165109.

For more information about this publication, contact: Director, USGS Upper Midwest Water Science Center 2280 Woodale Drive Mounds View, MN 55112 763-783-3100

For additional information, visit https://mn.water.usgs.gov

Publishing support provided by the

Rolla Publishing Service Center 


WATERSHIED

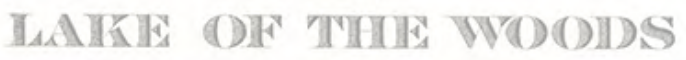

$\frac{\pi}{8}$

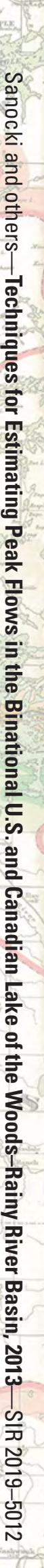

